\title{
The Role of Re-Appropriation in Open Design: A Case Study on How Openness in Higher Education for Industrial Design Engineering Can Trigger Global Discussions on the Theme of Urban Gardening
}
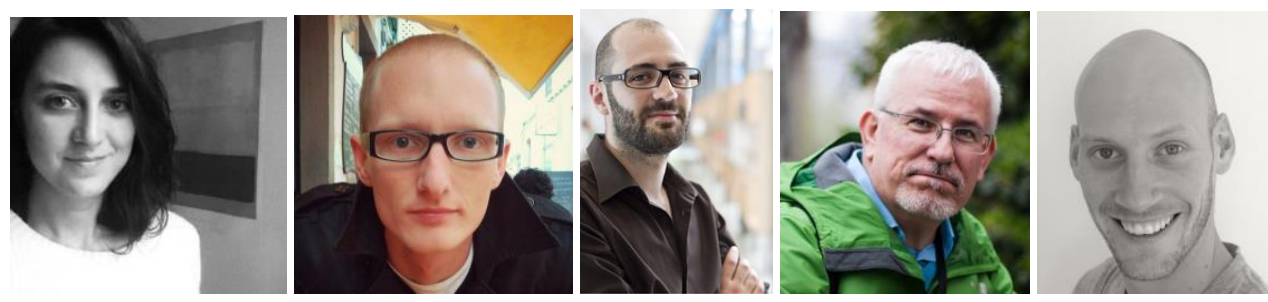

Francesca Ostuzzi'1, Peter Conradie'1, Lieven De Couvreur², Jan Detand ${ }^{1}$, and Jelle Saldien ${ }^{1}$ ${ }^{1}$ Department of Industrial Systems Engineering and Product Design, Ghent University, Belgium ${ }^{2}$ Howest, University of Applied Sciences, Belgium

\begin{abstract}
This case study explores the opportunities for students of Industrial Design Engineering to engage with direct and indirect stakeholders by making their design process and results into open-ended designed solutions. The reported case study involved 47 students during a two-weeks intensive course on the topic of urban gardening. Observations were collected during three distinctive phases: the codesign phase, the creation of an open design, and the sharing of these design solutions on the online platform Instructables.com.

The open sharing of local solutions triggered more global discussions, based on several types of feedback: from simple questions to reference to existing works and from suggestions to critiques. Also, some examples of re-appropriation of the designed solutions were reported. These feedbacks show the possibilities for students to have a global vision on their local solutions, confronting them with a wider and more diverse audience.

The case study shows, on the other hand, the difficulty in keeping students engaged in this global discussion, considering how after a few weeks the online discussions dropped to an almost complete silence. It is also very difficult with such online platforms to follow the re-appropriation cycles, losing the possibility of exploring the new local context where the replication/modification of the designed product occurred. The course's focus on open design is interesting from both the design and educational points of view. It implies a deep change in the teaching approach and learning attitude of students, allowing unknown peers to take part in the design process and fostering a global discussion starting from unique and local solutions.
\end{abstract}


Keywords: open design, industrial design, co-design, DIY, community-based practice, reusability, learning objects, adaptation process, open education

\section{Introduction}

Project based courses (or design laboratories) (Dymm, Agogino, Eris, Frey, \& Leifer, 2006) are a core activity for Industrial Design Engineering students. In such courses students are challenged to solve problems in valuable ways (functional, user-oriented, economic, environmental, etc.). This opportunity driven approach (trial and error) is the core of the design process and can be tackled in many different ways. In traditional design courses, the end results are shared with teachers and with a limited groups of experts (i.e., industries, design studio, potential final users, etc.), with the purpose of bringing the specific results closer to the actual stakeholders.

The design approach adopted in this study focuses on iterative cycles where many iterations with tangible prototypes are needed in order to achieve valuable solutions (Roozenburg \& Eekels, 1995). This process becomes a collaborative learning medium drawing on the learning approaches known as learning through doing or through experience, formalized by John Dewey (Dewey, 1997), experiential learning (Kolb, 1984) and reflective practice, by Donald Schön (Schön, 1983) which, independently from the achieved solution, sustains students' increasing their knowledge and skills. The accumulated expertise improves students' ability to understand and solve similar problems (Weber \& von Hippel, 2000). This expertise, in the form of embedded information, is defined as "sticky" (von Hippel, 1994)-meaning information is expensive to generate, acquire and transfer.

Design solutions can be distinguished depending on the relation between the end-use environment and the solutions itself, as in Figure 1 (below):

a) general solutions for global needs, mainly referring to the theoretically best material, best technology, etc. or

b) specific solutions for local needs, mainly referring to the available material, available technology, also defined as "appropriate." For description of "appropriate technology" see http://www.appropedia.org/Appropriate_technology.

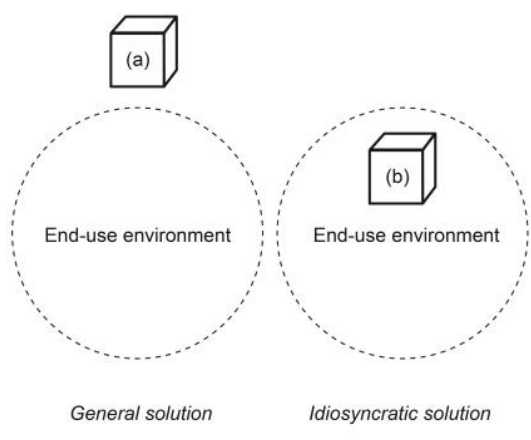

Figure 1. Relation between design solutions (general and specific) and end-use environment. 
In the case of general solutions (a), difficulties can be found while immersing students in the end-use environment. Examples include One Laptop Per Child (wiki.olpc.org), and NeoNurture (designthatmatters.org/neonurture). These solutions can be considered mainly technical, and may face problems during adoption and use phases: sometimes for real end-users the product loses its value due to the new context and faces non acceptance, or the user behaviour escalates, provoking the so-called rebound effect (Berkhout, Muskens, \& W. Velthuijsen, 2000). In the case of specific solutions (b), difficulties can be found while up-scaling these solutions in order to solve "global" problems. Examples could be provided by very contextual projects, as Design for Every (one) (designforeveryone.howest.be), and the EyeWriter (eyewriter.org).

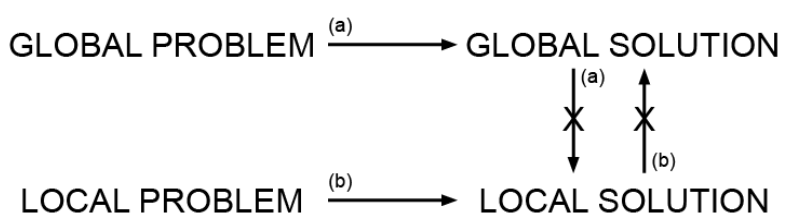

Figure 2. Arrows indicate the typical paths used to reach solutions (a) and (b). Crosses indicate where the difficulties can be found. For example: to reach solutions (b) designers start from local problems and reach unique and "appropriate" solutions. Difficulties can be found in the up-scaling process (from local to global) of these solutions.

These solutions, even if extremely valuable, risk remaining closed (because of the technical/cultural/linguistic skills required) and unconnected, as opposite to what stated in Manzini (2010). Typical paths to reach solutions (a) and (b), and related difficulties are synthetized in Figure 2. From our perspective these problems can be found both on the design method and educational level, as in Wiley and Hilton III (2009). In fact, for designers the solution (also defined as end result, final prototype, project, etc.) represents and sustains the learning process itself. In this context the solution can become a LO (Learning Object) to be shared in order to let other stakeholders learn through the achieved result, while our students can learn thanks to the discussion raised.

Our aim in this article is to explore how a more digital, open, connected kind of educational approach (Wiley \& Hilton III, 2009) in Industrial Design Engineering can stimulate reuse of design solutions and development of more personal solutions, and also to explore how these solutions can contribute to global discourse on issues related to sustainability. In the case study presented, the focus is on pushing specific solutions (b) to confront global problems (or, better, diffused problems). The main questions are: (a) Is it possible, thanks to these design initiatives, to stimulate conversation about local subjects in large participatory processes (Manzini \& Rizzo, 2011)? (b) What is the impact on students; how do they learn from this "global" dialog? (c) What aspects of the dialog actually stimulate and allow reuse and re-appropriation of the delivered solutions? 


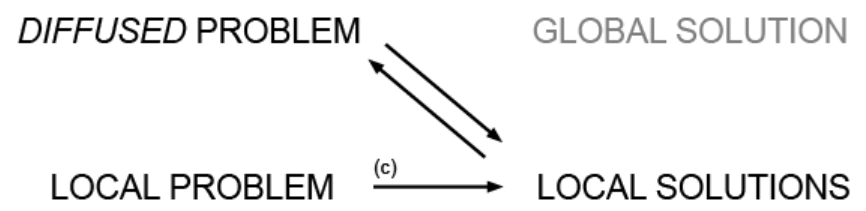

Figure 3. Path used in the present case study: from local problem to local solution. Through "global" discussions and re-appropriation cycles there is a chance to disseminate several local solutions.

The term "open" in our context refers to "the free revealing of information on a new design with the intention of collaborative development of a single design or a limited number of related designs for market or non-market exploitation" (Raasch, Herstatt, \& Balka, 2009, p. 383) and shares the goal of increasing the connectedness, personalization and participation as advocated in Wiley and Hilton III (2009). The broader goal of the research is, by helping students to understand how Industrial Design Engineers use OER (Open Educational Resources) type of contents, delivery and media, to stimulate students' engagement in global conversations in order to bring their local solutions in contact with diffused problems (Figure 3).

\section{Research Context: Sustainability and Openness in Design}

Sustainability is increasingly emphasized in courses on design and engineering (Melles, de Vere, \& Misic, 2011). Yet, while solutions may be applicable in a local context, they are not necessarily suited to be re-appropriated and reused on a wider scale, under both design and educational points of view (Chiappe \& Arias, 2015). The result is that sustainability focussed projects in design and engineering higher education are not always reused in other contexts, and it is also not clear how effective they might be. This represents a challenge to test our assumptions while trying to decrease the disconnect that exists between education systems and human society (defined as "supersystem" in Wiley \& Hilton III, 2009), and also a challenge regarding the approach of introducing sustainability into such a study course.

As Manzini and Rizzo (2011) note, to achieve new models for sustainable behaviour through participatory design, social innovation is necessary, in combination with an open process where small local activities interacts with different types of opportunities to achieve a large vision. Moreover, systemic problems such as those related to sustainability cannot be solved using the same reductionist techniques that caused them in the first place.

Several projects emphasise the role of urban gardening as a community-based project that allows sustainable consumption, and acts as a facilitator of social cohesion. Often in these kinds of projects we face a change from well-defined products or services with well-defined participants to a process for the realisation of a "socio-material assembly." In this process, the designer's role becomes that of a facilitator in the construction of a meaningful potentially controversial assembly, for and with the participants in the projects (Björgvinsson, Ehn, \& Hillgren, 2010). In this conceptual framework, the knowledge that rises from the designers' activities is captured, true to the the conception and implementation of "boundary objects" (Arias \& Fischer, 2000). This knowledge is embedded in the "non-human participants," such as prototypes, mock-ups, models, sketches, notes, and blogs that Björgvinsson et al. (2010) call "design devices” (Manzini \& Rizzo, 2011). 
One of the basic assumptions of this research is that industrial designers "learn through doing," for example through project-based learning (Dymm et al., 2006) and by "prototyping," meaning that pieces of hardware become the learning objects for these contexts (Tripp \& Bichelmeyer, 1990). A main goal for us, therefore, will be to explore how to seriously "open up the design process." Open design products are related to the open source movement. The open source movement, sustained by the Internet, allows collaborative creation of products (virtual and physical) by previously unrelated users. These realities question the dominant market's peculiarities-standardization, mass-orientation and closure-which are in contrast with the idea of "openness" (Maldini, 2014). In past years a systematic distance from the real user, and proximity with the "average" user for which "one size fits all," was often present. Nowadays, thanks to distributed production technologies and new consumption patterns, designers can focus more on local, decentralized, flexible, single-consumer oriented, open design (Igoe \& Mota, 2011). This new landscape is not ruled anymore by economies of scale, and presents real possibilities for innovating in niche markets (Oliveira, Zejnilovic, Canhao, \& von Hippel, 2015), creating a long tail of product adaptations (Anderson, 2006). Within this paradigm, a relationship with potential social change is also assumed, sustaining "openness" by the collaboration and interaction of diverse and connected communities (Maldini, 2014). It is important to mention that in software design the concept "openness" has been thoroughly applied and explored both under the points of view of licensing (i.e., open source) and the possibility of re-appropriations (i.e., Wikipedia), through highly iterative and shared processes. Also, in hardware design many projects and research projects focus around the topic of openness, but often focus mainly on the licensing and technological aspects (some famous cases have been analysed in Raasch et al., 2009), rather than on the ease of re-appropriations occurring after the design, which implies the real participation of different stakeholders. This last point is a crucial aspect of the present paper and can be defined also as the open-endedness of the product itself.

"Static artefacts" are in fact in contrast with open-designed objects, and are products fully defined by the professional designer, and do not anticipate any modification by the consumer (Hermans, 2014). Similarly to metadesign approaches, open design can be characterized by "the emergent properties of the interacting system rather than the conclusion obtained by one designer or one team of designers" (p. 16). Many open design interactions can be advocated as re-appropriations (meaning: understanding, copying and modifications on the original, core project) and facilitated by large communities.

Basically, "openness" means accessibility to view, modify and use a project (Avital, 2011); thus, transparency is advocated both in forms and contents. From a metaperspective, these reappropriation cycles can be sustained by "design spaces" or "solution spaces" (Hermans, 2014) and the resulting design behaviour can be considered as the actual users' space of freedom to express their own needs, desires, and possibilities. The freedom to express some situational differences (Avital, 2011) can be explored both on-line and off-line, in the physically proximate environment. The ecology of open design is highly complex and includes: design specification, fabrication, collaborative action, supply and value chain management, business models, legal aspects, technological infrastructure and normative values (Avital, 2011).

In this paper the advocated openness in design is on two levels: on the design (open design) level and on the educational (open learning and education) level. Open Educational Resources (D'Antoni, 2009; Friesen, 2009), in this case consisting of the project descriptions and step-by-step building instructions, were adopted to let the contents of the course reside in the public domain or have been 
released under an intellectual property license that permits their free use or re-purposing by others. Furthermore, this project draws upon open technologies and collaboration.

Born out of the idea to provide access to education to people who cannot obtain traditional forms of education (Dalsgaard \& Thestrup, 2015), Open Education (OE) existed well before the internet (Caswell, Henson, Jensen, \& Wiley, 2008). However, recent years have seen the convergence of factors that are resulting in advances in OE. These include the availability of online tools and increased community engagement (Iiyoshi \& Kumar, 2008). We view these trends as significant in also facilitating the shift from closed to open design.

In this way we adopted the Web 2.0 as a new participatory medium, where the students were put in contact with other potential consumers, designers, and general stakeholders, using platforms based on concepts of communication and participation (Gourley \& Lane, 2009; Seely Brown \& Adler, 2008).

How, in practice, to create an open design is not yet completely defined. We argue that to "open" the design two main steps are needed: (a) "physical" accessibility through online delivery (sharing the project, giving instructions, images, etc.); and (b) the "content creation," which means to restructure the content in order to facilitate reusability, also defined as re-appropriations (trying to simplify the understanding of the project and identifying the "solution spaces" mentioned before) (Chiappe \& Arias, 2015). To explore spontaneous open design behaviour we create a community-based practice within the context of urban gardening. Both steps have been explored during this case study, and represent crucial and complex dynamics.

\section{Method}

The case study presented in this paper is part of a larger study into the role of open design in transferring local co-designed solutions to global audiences in order to (a) trigger discussions, (b) improve the learning process of students, and (c) facilitate re-appropriation of projects. The course stimulated an active collaboration between students and stakeholders (both off-line and on-line) by being structured as an open process, where new actors can always enter, bringing new ideas, starting new dynamics and finding new solutions-what is defined as "social conversation" (Manzini \& Rizzo, 2011). Because the process was open, the final product also had to become open. This approach was chosen for its inner link with social innovation and sustainability. Unlike proprietary or branded products, open design solutions tend to be easy to maintain, repair locally (Thackara, 2011) and reappropriate. Furthermore, the design process that emerges is dynamic and the support of nondesigners may lead to conception and implementation of new solutions (Manzini, 2014). The aim was to show to students how to reach what Piller, Schubert, Koch, and Möslein (2005) define as "communities for co-design": on-line communities that are able to interact with features of products on-line. In such communities, solving technical problems, sharing practical experiences or adding/modifying some product features are real possibilities.

While Piller et al. (2005) focus on the customization of industrialized products, this case study deals with Do It Yourself (DIY) projects. This choice was made in order to facilitate dynamics of reappropriation of the provided solutions. In this research qualitative methods have been adopted. The main findings are presented in a narrative and descriptive way and were collected by researchers 
through continuous observation and communication between them and the students and between the students and different stakeholders.

\section{Course and Participants' Description}

The Intensive Program (IP) was a two-week intensive design course. The setting was a small FabLab where the main equipment consisted of: laser cutter, $3 \mathrm{D}$ printer (mainly Fused Deposition Modelling technology), CNC milling machine and other hand tools. Twelve teams were randomly created (eleven with four students, one with three) for a total of 47 students, all from the Bachelor of Science (BSc) program in Industrial Design Engineering Technology at the university where this study took place. On the first day of the program a document with the design brief was delivered to each team. Each team was matched with a stakeholder (also defined as "client") belonging to a local community. Contact details were given to students in order to allow direct communication. During the first week, while students were starting the co-design process, some lectures were given on permaculture, urban gardening and how to build instructions for Instructable.com. During the second week teams were mainly involved in prototyping their solutions, testing them and finally translating them into open design projects.

\section{Design Process}

The IP was divided into three main stages as shown below, in Figure 4.

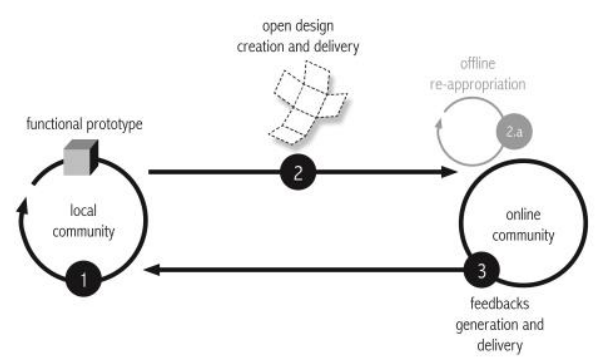

Figure 4. Design process adopted during IP 2014.

- Stage 1: Co-design process: from the design brief to the realization of one-piece functional prototype, made for local stakeholders (off-line, or analog).

- Stage 2: Realization of the open design: from the contents definition to the final delivery on Instructables.com (off-line and on-line, or analog and digital).

- Stage 3: Feedback from the online community: collecting insights and improving the project and/or instructions (on-line, or digital).

These three stages will also be used to structure the description of the results (see section headed "Results"). In Stage 1 and between Stage 2 and 3 a re-appropriation of the projects occurred. "Reappropriation" can be interpreted, for the sake of this research, as any action of understanding and/or copying and/or modifying locally developed solutions in a new context. This implies "untethering" the 
achieved solutions from their context, creating more "mobile" results, and following the trend of developing more "spatially accommodating" solutions (as in Wiley \& Hilton III, 2009). While in Stage 1 the students re-appropriate existing off-line resources and on-line projects, the second reappropriation is vice versa made by other stakeholders and happens in other unknown contexts and focuses on the newly developed projects. This last stage (2.a in Figure 4) is here only partially reported (see "Results" section). Potential future studies could explore this aspect in more detail.

As stated by Chiappe and Arias (2015) the LO (Learning Objects, in our case the end results of a design process) available online are not always structured in a way that facilitates reuse, reappropriation and adaptation. For this specific reason we selected Instructables.com as the sharing medium. Instructables.com is a collection of projects developed by different stakeholders. It represents for product designers what Connexions, Open Learn or other educational resources (for a selection see Friesen, 2009) can represent for other kinds of disciplines. The contents delivered should be accessible, low cost, and DIY, while the communication is in the form of step by step instructions, simple and supported by visuals (photos, sketches, etc.). Our goal is to explore possible ways to improve discussion and reuse of solutions developed in Industrial Design Engineering by adopting and developing an approach towards openness in higher education practical laboratories. We also acknowledged the concept of social learning, based on the premise that our understanding of content is constructed through conversations and through grounded interactions, especially with others (Seely Brown \& Adler, 2008).

\section{Deliverables}

To better address the research purposes (see section Research Context) some deliverables of the design process/project were suggested to the students, mainly related to: (a) Functional prototype, (b) documentation, (c) open design and (d) stakeholders' involvement (see Table 1). The objective was, using transparent and "real world" tools, to facilitate the re-appropriation of the solutions and sustain their validity.

Table 1

Required Deliverables of the Design Process and Solutions

Deliverables $\quad$ Format $\quad$ Purpose

(a) Product's $\quad$ Output must be a fully working Allow cycles of test in

functionality physical prototype (not just real environment of use

aesthetical or conceptual)

(b) Documentation $\quad$ Each team must keep a daily $\quad$ Facilitate re-

blog where the process is appropriation of the

described designed solutions

(c) Open design $\quad$ Share the final result online on Facilitate re- 


\begin{tabular}{lll}
\hline & $\begin{array}{l}\text { Instructables.com } \\
\text { Decide how to document the }\end{array}$ & \multicolumn{1}{c}{ appropriation of the } \\
designed solutions \\
solutions (project and process) \\
in a comprehensive way & \\
\hline involvement & Involve all the stakeholders & Ensure a clear focus on \\
& (on-line and off-line) in the & existing and specific \\
& discussion and co-design and & problems \\
& co-generative processes & \\
&
\end{tabular}

All these physical and virtual outputs have been used as a field to gather data for this research. With regard of data collection methods, every day the teachers' (the authors of this paper) consultations were given to each team (focused on both Stages 1 and 2) and in parallel, every two days, students were consulted with the purpose of understanding their learning process during the whole IP. To build up the presented figures all the students' blogs were constantly monitored, as well as the Instructables.com pages. A qualitative analysis of the feedback was conducted personally by the researchers. Finally, the use of public tools (in this case definable as OER), allows other researchers to consult and review the original data we used.

\section{Results}

The results description follows the structure of Figure 4, while the summary of the functional prototypes, blogs and Instructables.com pages can be found in Table 2 (below). Further information can be found at: sites.google.com/site/intensiveprogram2014/results.

Table 2

Summary of the Results

\begin{tabular}{|c|c|c|c|}
\hline Project & Image & $\begin{array}{c}\text { Blog } \\
\text { (links) }\end{array}$ & $\begin{array}{c}\text { Instructables.com } \\
\text { (links) }\end{array}$ \\
\hline $\begin{array}{l}\text { DIY Growing } \\
\text { potato tower } \\
\text { with turning } \\
\text { bins }\end{array}$ & & aardappelplantbak.blogspot.be & $\begin{array}{c}\text { instructables.com/id/DIY- } \\
\text { Growing-potato-tower-with- } \\
\text { turning-bins }\end{array}$ \\
\hline
\end{tabular}




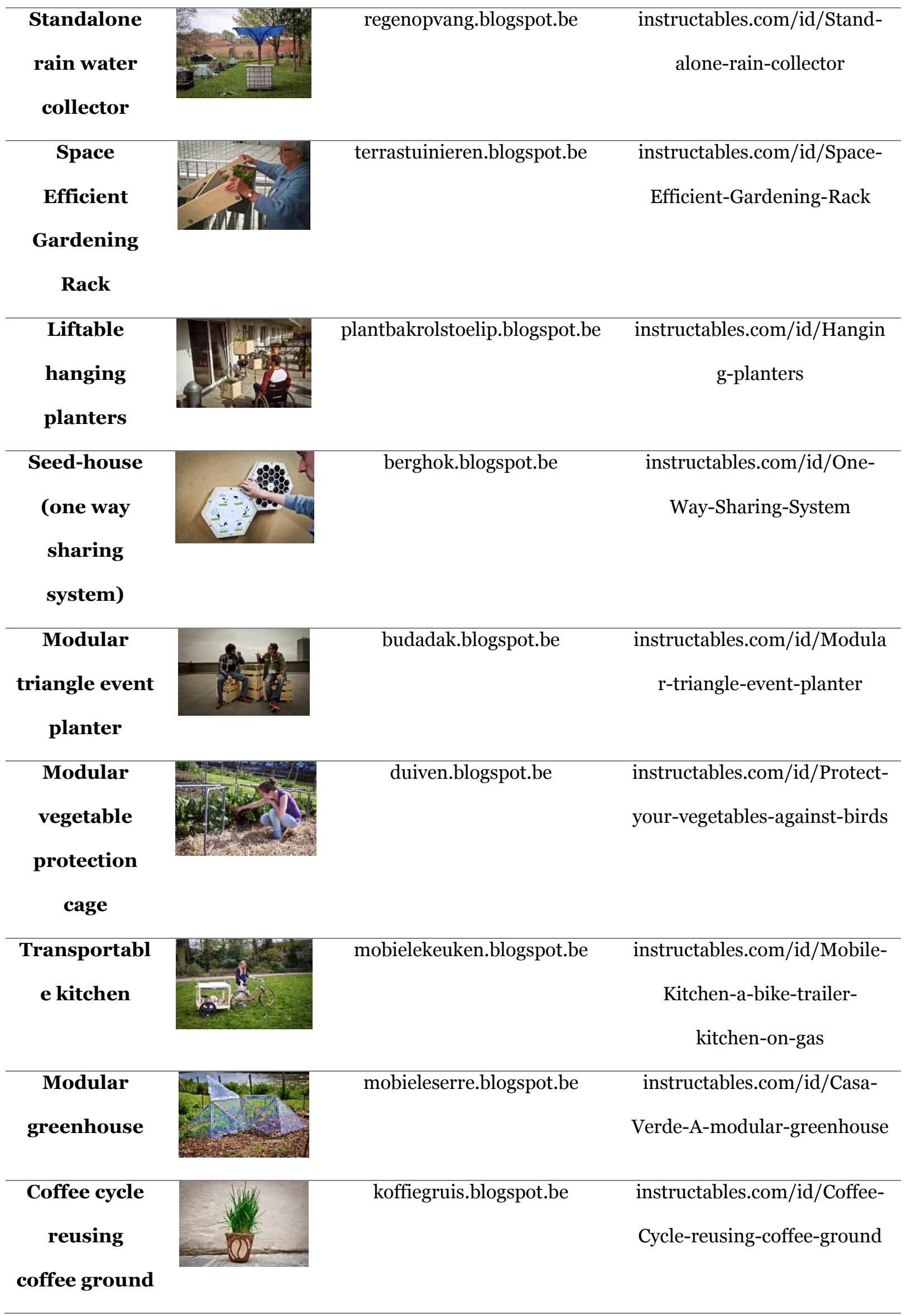




\begin{tabular}{ccc}
\hline Worm & wormcomposteerbak.blogspot.b & instructables.com/id/LARGE- \\
composter & e & EASY-TO-BUILD-WORM- \\
Celf-watering & bewatering.blogspot.be & instructables.com/id/How-to- \\
bin & & make-a-self-watering-bin
\end{tabular}

\section{Stage 1: Functional Prototype Realization}

Results of this stage derive from students' blogs, consultations, and functional prototypes. The realization of this last output corresponds with the end of Stage 1. This phase was characterized by a constant interfacing with the (off-line) stakeholders, following a co-generation process as described in De Couvreur and Goossens (2011) where all the actors involved communicate via prototypes, and tests are done in the physical, final environment of use. In addition, students were invited, but not obliged, to report the results of their tests in a simple matrix: expected/unexpected, positive/negative (De Couvreur, Dejonghe, Detand, \& Goossens, 2013). Specific results can be observed on the blogs. The purpose of this stage was to finalize a "highly contextual" functional prototype, which means without putting any effort into finding the "one size" that fits all. Results were approved by both teachers and stakeholders during a "go/no-go" presentation: all the prototypes were judged to be coherent with the brief, functional, and suitable to be translated into open designs.

This iterative co-design approach is well established (Dow \& Klemmer, 2011; Mao, Vredenburg, Smith, \& Carey, 2005). The added value in this case is in raising the students' awareness of the "contextual" design elements. Already, in this stage, re-appropriation cycles can be found: some students used already existing on-line open source solutions as a starting point for their own local design process (i.e., aardappelplantbakip2014.blogspot.be). In doing that they had mainly developed Stage 2.a in Figure 4, which means that they had to understand what aspects of the existing projects were for them useful, repeatable and feasible in their own context.

\section{Stage 2: Creation and Upload of Open Designs}

Results of this stage are derived from personal consultations and Instructables.com pages. These results show the value of connecting people and contents via the web. They are divided into the creation of the open design (content) and its delivery.

Creation. Students were first asked to reflect on what contents (design elements, final output image, instructions, etc.) should be delivered. They also had the possibility of slightly changing the design specifications in order to make it easier to be re-appropriated. Their choices were supported by literature (Dahl \& Moreau, 2007) and by constant consultations with teachers. Other concepts applicable to the stimulation of reusability through open education were applied to the content creation (our Learning Objects) in order to create less contextualized content, improve use granularity (i.e., solutions were divided into independent sub-solutions to be applied to different contexts) and stimulate adaptation as described below (Chiappe \& Arias, 2015). 
Consultations were focused on the exploration of the design elements, trying to divide them into "contextual" (highly context-linked) variables, and "fixed" variables, as listed in Ostuzzi, Rognoli, Saldien, and Levi (2015). This process was developed in order to avoid any information overload (Dahl \& Moreau, 2007) or other hindrances. For students both the understanding of the concept and the identification of these elements was extremely easy: the iterative co-design process probably helped them distinguish, for example, between a choice made because "laser cutter is the only available machine" or because "laser cutter is probably the best technology for such a geometry/material/etc.” (i.e., berghok.blogspot.be). Furthermore, these consultations helped teachers' understanding of students' level of knowledge about aspects of technical design.

Delivery. To deliver the open designs, the students were asked to create online instructions. Various supports related to this topic are available (Dalton, Desjardins, \& Wakkary, 2014).

End results can then be seen as "open" not only because freely available on-line, but also because of the effort of "openness" while designing them (defined as open design). Examples include, but are not limited to:

- Use of modularity;

- Use of standard pieces (screws, bolts, profiles, etc.);

- No defined dimensions (instructables.com/id/Space-Efficient-Gardening-Rack/?ALLSTEPS), but rather guidelines to suit the context of use;

- Written or visual proposal of alternatives (see Figure 5, below).

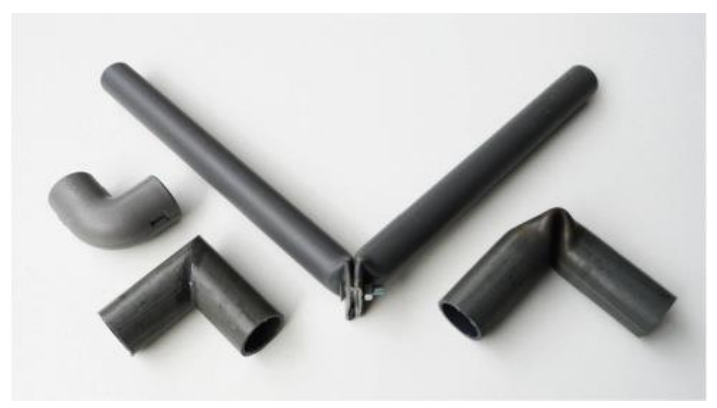

Figure 5. Alternative ways to create a $90^{\circ}$ joint, listed by Modular vegetable protection cage projects.

It is interesting to note that the majority of these solutions-freely defined by students and primarily meant to enable and facilitate the (also conceptual) re-appropriation of their projects from different stakeholders-are basically LCD (Life Cycle Design) strategies that also confirm previous assumptions about the relationship between open design and sustainability (Cooper, 2010, Vezzoli \& Manzini, 2008).

\section{Stage 3: On-line Community}

Results of this stage derive mainly from the observation of on-line interaction. The "opening" of the process and end results had the goal of stimulating a global and social conversation with unknown and unrelated stakeholders in order both to get useful insights and to verify the ease of the reappropriation dynamics. This brought to students very practical answers regarding the perception and 
application of their solutions and gave them interesting and not generic "off the shelf" information (as defined by Wiley \& Hilton III, 2009). Furthermore, the conversation stimulated students to improve some solutions, representing a real completion of the assignment outside the class and academia itself. A constant on-line monitoring by researchers occurred during the 18 months after the on-line publication (from February, 2014 to August, 2015). The number of views and comments decreased after a few weeks. The projects able to start this conversation are highlighted in Table 3, below (to read the actual comments, see Appendix 1 or Instructables.com pages). Comments were grouped as:

- Questions;

- Related works;

- Suggestions;

- Critiques;

- "I've made it";

- (Not-) supportive.

It was decided to report, in a narrative way, only comments pertaining to the first five categories. The (not-) supportive comments are generally not meant to start any discussion (i.e. "Good idea!"). All the comments, and their exact number, are reported in their complete version in Appendix 1.

Table 3

The Combinations of Projects with Specific Types of Comments are Marked with " $x$ "

\begin{tabular}{|c|c|c|c|c|c|}
\hline Project & 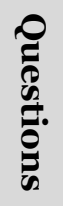 & $\begin{array}{ll}\pi \\
0 \\
0 \\
0 \\
0\end{array}$ & 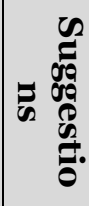 & م: & 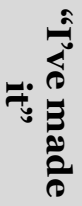 \\
\hline $\begin{array}{l}\text { DIY Growing potato tower with turning } \\
\text { bins }\end{array}$ & $\mathrm{x}$ & $\mathrm{x}$ & $\mathrm{x}$ & $\mathrm{x}$ & $\mathrm{x}$ \\
\hline Standalone rain water collector & $\mathrm{x}$ & $\mathrm{x}$ & $\mathrm{x}$ & $\mathrm{x}$ & $\mathrm{x}$ \\
\hline Space Efficient Gardening Rack & & & & & \\
\hline Liftable hanging planters & & & $\mathrm{x}$ & & \\
\hline Seed-house (one way sharing system) & & & $\mathrm{x}$ & $\mathrm{x}$ & $\mathrm{x}$ \\
\hline Modular triangle event planter & & & & & \\
\hline Modular vegetable protection cage & & & $\mathrm{x}$ & & $\mathrm{x}$ \\
\hline Transportable kitchen & & & & & \\
\hline
\end{tabular}




\begin{tabular}{|l|l|l|l|l|l|}
\hline Modular greenhouse & & & $\mathrm{x}$ & & $\mathrm{x}$ \\
\hline Coffee cycle reusing coffee ground & & $\mathrm{x}$ & $\mathrm{x}$ & & $\mathrm{x}$ \\
\hline Worm composter & & & & & \\
\hline Self-watering bin & & & & & \\
\hline
\end{tabular}

Questions. These comments are questions (around functions, costs, maintenance, etc.) submitted in order to better understand the project (i.e. "How do you address the issue of overfilling?"; "Can you explain the purpose of turning the bin..?”, etc.). To ask a question can be considered the most direct way to explore new items, and the fact that these questions were on-line, in a public medium, and asked for "black and white" answers, often pushed students to rethink and restructure their projects and instructions. One example, (instructables.com/id/One-Way-SharingSystem) where, thanks to some comments, the students understood how to improve their video and the way they deliver information to unknown audiences.

Previous works. Some comments referred to existing related projects trying, for example, to argue why one solution was better than the other. Some internal or personal references were also used (i.e. "Reminds me of my experience at instructables.com/id/..."). Because the IP took place within a very brief time frame these comments provided the students with some inspiration and challenges, inspiring them to further effort if a proper "state of the art" had not yet been developed or even bringing insights not reachable otherwise.

Suggestions. Students received suggestions, in the form of tips, practical ideas, and possible improvements on the project instructions. Sometimes the suggestions were visual-see Figure 6 ("Green tarp would have been a better option."; "Actually - you can redesign it so that you have an entire string of them...One perhaps as a dead weight / counter balance at the end? and a whole string of them in a row.").

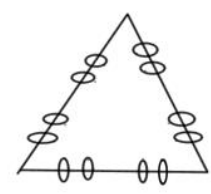

Figure 6. "Is there any reason you could not skip the rectangles and just use cable/zip ties to form a loop through each hole? Then they would act as the hinge too. I hope my sketch will help explain.”

These comments helped students to improve their solutions, and represent useful tips, especially for other users wanting to copy the project. Some suggestions drew attention to contextual aspects not previously recognized by students or teachers ("If you're in the US, be careful that you aren't violating (dumb) rainwater collection laws. I know where I live, you need a permit to collect any rainwater").

Critiques. Comments also expressed doubt about the functioning or value of projects (i.e., "This is just a nicer looking alternative to a tower made from a stack of old tires"), and are often 
followed by suggestions and/or related works. These comments pushed students to explain the motivations for the existing solutions (when in disagreement with the critique), or to find new solutions (when in agreement with the critique). In specific cases safety issues were pointed out (i.e., "An intelligent person minimizes risks to him/herself. A teacher helps others to minimize risks to all of us (in part)"). Apart from the specific case this last comment refers to, it raises a very interesting issue related to open design and education: to what extent is it the responsibility of the creator?

"I've made it." This feedback is probably the most interesting in terms of identification of contextual and fixed design elements; in fact, it again pulls the project into the off-line and local dimension (i.e., "I will have to try this. I live in North Idaho were the growing season is very short so this seems like an excellent cost effective solution to jump start the growing season"). Some examples developed this re-appropriation process from the understanding of the project to its (modified) realization; these comments were often accompanied by visuals ("I made mine out of steel tubing and used chicken wire on them too. I used mine as mulch cubes" (Figure 7a) and "I used tie raps to secure the basket to my bike. It's very secure and I love it!" (Figure 7b)).
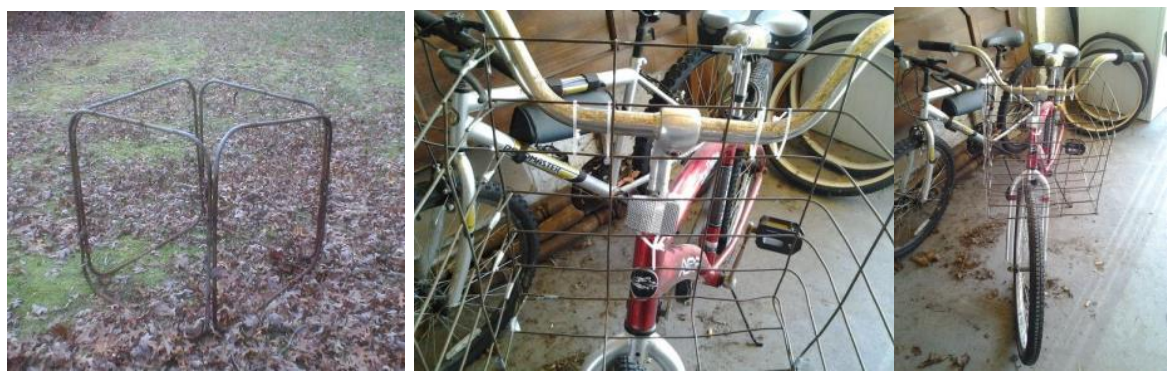

Figure $7(a, b)$. Examples of re-appropriation, uploaded in Instructables.com

In these examples changes are made: materials and dimensions are, for example, different. Users declared that they used what was available to them, or what suited their environment best. In this sense a sort of "design after design" was shown to students: a dimension where their idea has taken different shapes and, again off-line, helped to solve someone's practical problems.

\section{Discussion}

In this case study we stimulated students' engagement in a process of opening education and its end results. The university acted as mediator of a new approach towards openness (Wiley \& Hilton III, 2009) trying to orientate and sustain students while interfacing with different (unknown) stakeholders.

In two weeks it was already possible to understand the value of this approach, specifically when adopted in Industrial Design Engineering courses. First of all, design students' solutions were taken outside the academic environment to reach an online platform (Instructables.com). This approach allowed students to increase their number of peers (with an average of 19,900 views for each upload, and a peak of more than 62,000 views for the Seed-house project) and see their own solutions evaluated, developed, criticized, re-appropriated, etc. by unknown stakeholders. In particular, it was 
thanks to the comments-the real medium of this global conversation-that students could collect some "lessons learned," which led to real changes in their projects and/or on-line instructions.

For example, comments in the form of questions showed to students how certain information, originally well understood or at least understandable by off-line peers, was completely unclear for online communities. As seen, some suggestions and/or "I've made it" comments confronted students directly with a re-appropriation process where they had to "lose control" over their own solution in order to make it suitable in different contexts. This approach, with its open-ended design elements (e.g. material, shape, production techniques) is theorized in different studies (e.g., van Hinte, 1997) but is sometimes hard to be visualized and explored by students in their practice. It is a known fact that the personalization and realization of products can add value to the user-product relation in terms of retaining time and satisfaction (e.g., Dahl \& Moreau, 2007; Schifferstein \& ZwartkruisPelgrim, 2008), but it is still hard to teach students how to achieve this in practice.

Furthermore, given that Industrial Design Engineering is a very broad discipline, there is always the need (for the academic staff) to involve experts of specific fields during the design process and the assessment of the end results. In this case study this need was automatically satisfied by the sharing of the end results, thank to which students managed to find experts in real and different application fields also unknown to their teachers.

It's important to underline that the research problem (as defined in the "Research Context" section of this paper) is difficult (Rittel \& Webber, 1973). Many limitations emerged, mainly linked to low student engagement, to the choice of the on-line medium (which, for example, gives visibility for just few weeks), or to the difficulty in tracking all communication and connecting causes and consequences in a linear way. For these reasons this study adopted a mere observational point of view, with the purpose of testing the dynamic and identifying some aspects that can be more deeply explored in future studies (see section Conclusions and Future Studies). A big limitation was also the language barrier. Students were asked to write their blogs in English, but some of them naturally switched to their native Dutch to make communication easier and less stressful, especially with the local stakeholders.

In general, the goal of joining a global conversation and visualizing re-appropriation processes was achieved. Users, both on-line and off-line, had unique solutions, based on what was more available and/or more suitable to their contexts. These concepts are linked to sustainability, appropriate technologies and education. Also, the goal of a first exploration of OER delivery practices for Industrial Design Engineers was achieved, giving a first understanding of the kind of media and content useful for such a field, creating extended connections with shared and distributed practicums to develop new experiences from new and unknown contexts, as advocated in Seely Brown and Adler (2008).

\section{Conclusion and Future Studies}

This paper has presented the findings of a research project focused on the topic of teaching to Industrial Design Engineering students how to deal with the "opening" process of their design solutions in order to obtain dynamics of conversation, reuse (re-appropriation of the solutions) and potential improvement of their educational material that is represented by the product itself. The 
findings consolidate the idea that working with open design, while teaching sustainability to designers, represents an effective reality-based way of learning and confronting students with unknown contexts and potential peers. As advocated by Wiley and Hilton III (2009) the openness of the education implied connections with unknown stakeholders, the personalization of the shared material and the creation of new solutions, improving the existing ones. In conclusion, the results of this practical case study highlight the potential of open design to encourage students to think about sustainable issues involving real stakeholders in all phases. The open designs combined with online instructions on an accessible platform allow the transfer from local solutions to global discussions, opening the education. A few practical adaptions were made to transform local and context-based solutions into a more open design, and to not just transfer these solutions online. The goal of this additional passage was to facilitate reuse and learning experience, rather than just publish the end results as they were in their analogical version (that is, Stage 1, Figure 4).

In general, we believe that the educational system should stimulate the ability of Industrial Design Engineering students to create more open design while engaging in the co-design of local solutions but with a potential global impact. This will support a constant reflection about the achieved solutions, involving different stakeholders rather than just the academic ones, and improve the solutions' sufficiency (Vezzoli \& Manzini, 2008). Open design can be a powerful engine able to help students while solving difficult problems. Thanks to the opening of the design process, implemented by the universities, this innovative teaching can keep students relevant and connected with the current scene; furthermore, the fact that open designs are meant to change with changed requirements stimulates students (and, in general, designers) to look at the world through the eyes of their stakeholders, engaging in new off-line/on-line co-experiences.

\section{References}

Anderson, C. (2006). The Long Tail. Why the Future of Business Is Selling Less of More. Hyperion.

Arias, E. G., \& Fischer, G. (2000). Boundary objects: Their role in articulating the task at hand and making information relevant to IT. Center for LifeLong Learning \& Design and Institute of Cognitive Science Department of Computer Science, and College of Architecture and Planning Univers. Architecture, 1-8.

Avital, M. (2011). The generative bedrock of open design. In B. van Abel, L. Evers, R. Klaassen, \& P. Troxler (Eds.), Open design now: Why design cannot remain exclusive, (pp. 48-58). Amsterdam: BIS Publishers.

Berkhout, P. H. G., Muskens, J. C., \& Velthuijsen, J. W. (2000). Defining the rebound effect. Energy Policy, 28(6-7), 425-432. doi.org/10.1016/So301-4215(00)0o022-7

Björgvinsson, E., Ehn, P., \& Hillgren, P.-A. (2010). Participatory design and "democratizing innovation." In Proceedings of the 11th Biennial Participatory Design Conference (pp. 4150). New York: ACM Press. doi.org/10.1145/1900441.1900448

Caswell, T., Henson, S., Jensen, M., \& Wiley, D. (2008). Open content and open educational resources: Enabling universal education. International Review of Research in Open and 
Distributed Learning, 9(1), 1-11.

Chiappe, A., \& Arias, V. (2015). Understanding reusability as a key factor for open education : A review. International Review of Research in Open \& Distance Learning, 16(1), 40-57.

Cooper, T. (2010). Longer Lasting Products Alternatives to the Throwaway Society. (Intergovernmental Panel on Climate Change, Ed.) Gower publishing Limited. Cambridge: Cambridge University Press. doi:org/10.1017/CBO9781107415324.004

Dahl, D. W., \& Moreau, C. P. (2007). Thinking inside the box: Why consumers enjoy constrained creative experiences. Journal of Marketing Research, 44(3), 357-369. doi.org/10.1509/jmkr.44.3.357

Dalsgaard, C., \& Thestrup, K. (2015). Dimensions of openness: Beyond the course as an open format in online education. International Review of Research in Open and Distance Learning, 16(6), 78-97. doi.org/10.19173/irrodl.v16i6.2146

Dalton, M. A., Desjardins, A., \& Wakkary, R. (2014). From DIY tutorials to DIY recipes. In Extended abstracts of the 32nd annual ACM conference on human factors in computing systems - CHI EA '14 (pp. 1405-1410). New York: ACM Press. doi.org/10.1145/2559206.2581238

D’Antoni, S. (2009). Open educational resources: Reviewing initiatives and issues. Open Learning: The Journal of Open and Distance Learning, 24(1), 3-10. doi.org/10.1080/02680510802625443

De Couvreur, L., Dejonghe, W., Detand, J., \& Goossens, R. (2013). The role of subjective well-being in co-designing open-design assistive devices. International Journal of Design, 7(3), 57-70.

De Couvreur, L., \& Goossens, R. (2011). Design for (every)one : Co-creation as a bridge between universal design and rehabilitation engineering. CoDesign, 7(2), 107-121. doi.org/10.1080/15710882.2011.609890

Dewey, J. (1997). Experience and Education. Touchstone (Touchstone). New York, New York, USA: Simon \& Schuster.

Dow, S. P., \& Klemmer, S. R. (2011). The efficacy of prototyping under time constraints. In H. Plattner et al. (Eds.), Design thinking: Understand-improve-apply, (pp. 111-128). Berlin, Heidelberg: Springer. doi.org/10.1007/978-3-642-13757-0_7

Dymm, C. L., Agogino, A. M., Eris, O., Frey, D. D., \& Leifer, L. J. (2006). Engineering design thinking, teaching, and learning. IEEE Engineering Management Review, 34(1), 65-65. doi.org/10.1109/EMR.2006.1679078

Friesen, N. (2009). Open educational resources: New possibilities for change and sustainability. International Review of Research In Open And Distributed Learning, 1O(5), 1-13. Retrieved from http://www.irrodl.org/index.php/irrodl/article/viewArticle/664

Gourley, B., \& Lane, A. (2009). Re-invigorating openness at The Open University: the role of open educational resources. Open Learning: The Journal of Open and Distance Learning, 24(1), 
37-41. doi.org/10.108o/02680510802627845

Hermans, G. (2014). Investigating the unexplored possibilities of digital - physical toolkits in lay design. International Journal of Design, 8(2), 15-28.

Igoe, T., \& Mota, C. (2011). A strategist's guide to digital fabrication. Strategy \& Business, (64), 2010-2011.

Iiyoshi, T., \& Kumar, M. (2008). Opening up education. Cambridge: MIT Press.

Kolb, D. A. (1984). Experiential learning: Experience as the source of learning and development. Englewood Cliffs, NJ: Prentice-Hall.

Maldini, I. (2014). From "Do it yourself" to "Open design": Users' involvement and democratization. In Design Frontiers: territories, concepts, technologies. 8th Conference of the International Commitee for Design History \& Design Studies. (pp. 364-367). doi.org/10.5151/designicdhs-080

Manzini, E. (2010). Small, local, open and connected: Design for social innovation and sustainability. The Journal of Design Strategies - Change Design, 4(1), 56-61.

Manzini, E. (2014). Making things happen: Social innovation and design. Design Issues, 30(1), 57-66. doi.org/10.1162/DESI_a_00248

Manzini, E., \& Rizzo, F. (2011). Small projects/large changes: Participatory design as an open participated process. CoDesign, 7(3-4), 199-215. doi.org/10.1080/15710882.2011.630472

Mao, J.-Y., Vredenburg, K., Smith, P. W., \& Carey, T. (2005). The state of user-centered design practice. Communications of the ACM, 48(3), 105-109. doi.org/10.1145/1047671.1047677

Melles, G., de Vere, I., \& Misic, V. (2011). Socially responsible design: thinking beyond the triple bottom line to socially responsive and sustainable product design. CoDesign, $7(3-4), 143-154$. doi.org/10.1080/15710882.2011.630473

Oliveira, P., Zejnilovic, L., Canhao, H., \& von Hippel, E. (2015). Innovation by patients with rare diseases and chronic needs. Orphanet Journal of Rare Diseases, 10(41), 194-201. doi.org/10.1186/s13023-015-0257-2

Ostuzzi, F., Rognoli, V., Saldien, J., \& Levi, M. (2015). +TUO project: low cost 3D printers as helpful tool for small communities with rheumatic diseases. Rapid Prototyping Journal, 21(5), 491505. doi.org/10.1108/RPJ-09-2014-0111

Piller, F., Schubert, P., Koch, M., \& Möslein, K. M. (2005). Overcoming mass confusion: Collaborative customer co-design in online communities. Journal of Computer-Mediated Communication, $10(4), 1-25$.

Raasch, C., Herstatt, C., \& Balka, K. (2009). On the open design of tangible goods. R\&D Management, 39(4), 382-393. doi.org/10.1111/j.1467-9310.2009.00567.x 
Rittel, H. W. J., \& Webber, M. M. (1973). Dilemmas in a general theory of planning. Policy Sciences, 4, $155^{-169 .}$

Roozenburg, N. F. M., \& Eekels, J. (1995). Product design: Fundamentals and methods (Vol. 2). Chichester: Wiley.

Schifferstein, H. N. J., \& Zwartkruis-Pelgrim, E. P. H. (2008). Consumer-product attachment: Measurement and design implications. International Journal of Design, 2(3), 1-13.

Schön, A. D. (1983). The Reflective Practioner. Journal of Chemical Information and Modeling, 53, 16o. http://doi.org/10.1017/CBO9781107415324.004

Seely Brown, J., \& Adler, R. P. (2008). Minds on fire. Open education, the long tail and learning 2.o. Educause Review, (January/February), 18-32.

Thackara, J. (2011). Into the open. In B. van Abel, L. Evers, R. Klaassen, \& P. Troxler (Eds.), Open design now. Why design cannot remain exclusive (pp. 42-45). Amsterdam: BIS Publishers. Retrieved from http://opendesignnow.org/

Tripp, S. D., \& Bichelmeyer, B. (1990). Rapid design prototyping: An alternative instructional design strategy. Educational Technology Research \& Development, 38(1), 31-44. doi.org/10.1007/BFo2298246

van Hinte, E. (1997). Eternally yours: Visions on product endurance. Rotterdam: 010 Publishers.

Vezzoli, C., \& Manzini. (2008). Design for Environmental Sustainability. London: Springer London. doi.org/10.1007/978-1-84800-163-3

von Hippel, E. (1994). "Sticky information" and the locus of problem solving: Implications for innovation. Management Science, 4O(4), 429-439. doi.org/10.1287/mnsc.40.4.429

Weber, C., \& von Hippel, E. (2000). Maximizing profitability through easy information transfer. 2000 IEEE/SEMI Advanced Semiconductor Manufacturing Conference and Workshop. ASMC 2000 (Cat. No.ooCH37072), (pp. 250-255). doi.org/10.1109/ASMC.2000.902596

Wiley, D., \& Hilton III, J. (2009). Openness, dynamic specialization, and the disaggregated future of higher education. International Review of Research in Open and Distributed Learning, 1O(5), 1-16. Retrieved from http://www.irrodl.org/index.php/irrodl/article/view/768 


\section{Appendix 1}

$\begin{array}{ll}\text { Project Comments } & \text { Coment }\end{array}$

\begin{tabular}{|c|c|c|}
\hline \multirow{5}{*}{$\begin{array}{l}\text { DIY } \\
\text { Growing } \\
\text { potato } \\
\text { tower with } \\
\text { turning } \\
\text { bins }\end{array}$} & Questions & $\begin{array}{c}\text { "Can you explain the purpose of turning the bin..?" } \\
\text { "Why do potatoes need to be heightened?" } \\
\text { "Is there any reason for concern with regards to chemical leaching from } \\
\text { the low grade plastic?” }\end{array}$ \\
\hline & $\begin{array}{l}\text { Previous } \\
\text { works }\end{array}$ & $\begin{array}{l}\text { "The first (and most simple) potato tower I saw, was simply a tire } \\
\text { placed on the ground" } \\
\text { "I done this myself last year but with used tires and kept building tires } \\
\text { up as we went." } \\
\text { "This is a very interesting way to make a "neat" solution to what we did } \\
\text { when I was a lad." }\end{array}$ \\
\hline & Suggestions & $\begin{array}{l}\text { How about lining the inside with aluminium foil and face towards the } \\
\text { sun?" } \\
\text { "A great tip I got from an accomplished grower: Start off with } \\
\text { soil/compost mix or blood and bone mix or similar.” }\end{array}$ \\
\hline & Critiques & $\begin{array}{c}\text { This is just a nicer looking alternative to a tower made from a stack of } \\
\text { old tires" } \\
\text { "also on the last video, I only saw one potato come out..." }\end{array}$ \\
\hline & $\begin{array}{l}\text { "I've made } \\
\text { it" }\end{array}$ & $\begin{array}{c}\text { "I am interested in testing your system. I live in Merelbeke: } \\
\text { xxx.yyy@gmail.com" }\end{array}$ \\
\hline \multirow[t]{3}{*}{$\begin{array}{l}\text { Stand- } \\
\text { alone rain } \\
\text { water } \\
\text { collector }\end{array}$} & Questions & $\begin{array}{c}\text { "What do you do about leaves and other debris?" } \\
\text { "How do you address the issue of over-filling?" } \\
\text { "Where did you find the container, and how much was it?" } \\
\text { "Can you estimate how much rain it takes to fill the tote. Like, how } \\
\text { much rainfall equivalent in inches would it take for the tarp to fill the } \\
\text { tote?” }\end{array}$ \\
\hline & $\begin{array}{l}\text { Previous } \\
\text { works }\end{array}$ & $\begin{array}{l}\text { "I have seen a documentary on at least one company harvesting } \\
\text { rainwater for bottled water using exactly this kind of thing... they use a } \\
\text { similar design that folds down when it isnt raining (which saves a lot of } \\
\text { sun damage etc..) and they open it up when it rains..." }\end{array}$ \\
\hline & Suggestions & $\begin{array}{l}\text { "Green tarp would have been a better option.” } \\
\text { "One important thing--the plastic of the IBC MUST be protected from } \\
\text { the sun--otherwise it will deteriorate and eventually crack--AND it will } \\
\text { soon start to grow algae wherever the sun strikes it." } \\
\text { "Then you could put some chairs around it and voila---you have a cool } \\
\text { place to have lunch...Hmmmmm--Now that I like--and maybe I will } \\
\text { make one....." } \\
\text { "If you're in the US, be careful that you aren't violating (dumb) } \\
\text { rainwater collection laws. I know where I live, you need a permit to } \\
\text { collect any rainwater." } \\
\text { "Great insights on state laws and regulations applicable to one's } \\
\text { location." } \\
\text { "Here in S. Nevada the sun and wind would beat that tarp up in no } \\
\text { time,..I think I'll make it auto open/close with arduino and water } \\
\text { sensor." }\end{array}$ \\
\hline
\end{tabular}


"Wondering about an adaptation to this great idea that would include a solar distillation unit for purification of the water to make it potable."

Critiques "Great idea but you need to know that the type of tarp/canvas you used is treated with water repellant at the factory and is not suitable for potable water / human consumption."

"An intelligent person minimizes risks to him/herself. A teacher helps others to minimize risks to all of us (in part). I can only wonder at why anyone would have an issue with a potential health risk being pointed out, or is it more that anyone dares to disagree with you at all?"

"I've made "I have a community garden [...]. There have been some weeks with no it" rain, so we're thinking of setting up a 2nd tank for a back-up. This may help, thanks!"

"A lot of people using tank water for home use don't have enough to water their veggie gardens at peak growing time. I'm going to send a link to a New Zealand on line gardening magazine if it is okay with you." "This idea is excellent and I'm building one (or several units) myself for a remote property I'm developing as a place of retreat and recollection."

"Here in S. Nevada the sun and wind would beat that tarp up in no time,..I think I'll make it auto open/close with arduino and water sensor."

"Great concept guys/girls, I'm seeing some possibilities with materials that are easy to obtain where I live."

\begin{tabular}{|c|c|c|}
\hline \multirow{5}{*}{$\begin{array}{l}\text { Space } \\
\text { Efficient } \\
\text { Gardening } \\
\text { Rack }\end{array}$} & Questions & $\mathrm{x}$ \\
\hline & $\begin{array}{l}\text { Previous } \\
\text { works }\end{array}$ & $\mathrm{x}$ \\
\hline & Suggestions & $\mathrm{x}$ \\
\hline & Critiques & $\mathrm{x}$ \\
\hline & $\begin{array}{l}\text { "I've made } \\
\text { it" }\end{array}$ & $\mathrm{x}$ \\
\hline \multirow{5}{*}{$\begin{array}{l}\text { Liftable } \\
\text { hanging } \\
\text { planters }\end{array}$} & Questions & $\mathrm{x}$ \\
\hline & $\begin{array}{l}\text { Previous } \\
\text { works }\end{array}$ & $\mathrm{x}$ \\
\hline & Suggestions & $\begin{array}{l}\text { "This is great, as a tip for those that make it, if you are growing } \\
\text { vegetables in these some vegetables grow faster than others so to } \\
\text { counter that hang bottles of water from the with the appropriate } \\
\text { amount of water in the to keep balanced, I've made something similar } \\
\text { previously" } \\
\text { "Actually - you can redesign it so that you have an entire string of } \\
\text { them....One perhaps as a dead weight / counter balance at the end? and } \\
\text { a whole string of them in a row." }\end{array}$ \\
\hline & Critiques & $\mathrm{x}$ \\
\hline & $\begin{array}{l}\text { "I've made } \\
\text { it" }\end{array}$ & $\mathrm{x}$ \\
\hline \multirow{3}{*}{$\begin{array}{l}\text { Seed-house } \\
\text { (one way } \\
\text { sharing } \\
\text { system) }\end{array}$} & Questions & $\mathrm{x}$ \\
\hline & $\begin{array}{l}\text { Previous } \\
\text { works }\end{array}$ & $\mathrm{x}$ \\
\hline & Suggestions & $\begin{array}{c}\text { Have you considered turning the leftover honeycomb shaped pieces into } \\
\text { containers and using those instead? you'd have a guaranteed perfect fit. } \\
\text { just label the ends or add chalkboard paint." }\end{array}$ \\
\hline
\end{tabular}

"Using one inner plate less would work as a nice spice rack or storage for assorted bits and pieces. Regarding the "locking" mechanism: One 
inner plate more and the top plate a little set off upwards (or inner sections downwards) could provide interlocking of the jars only by gravitational force. This way you could use a "key" to rise the inner sections a little (or lower the front panel) and the jars would be pushed out by a spring tensioned (now in the other direction) back plate. So no need for magnets anymore and some parts less."

Critiques "I don't quite understand how to use it. And what about the hex bottles?"

"Nice design, but couldn't you just use a suction cup to pull the jars out?"

"I am confused by this, if someone wanted to steal jars, couldn't they just screw in a bolt and then access the jars?"

"but if I have a bolt I can open it, not just the person in charge" "Could I steal a jar with a simple sucker?"

"It would seem that you could easily pry a jar out with a knife or similar object as well"

\begin{tabular}{|c|c|c|}
\hline & $\begin{array}{l}\text { "I've made } \\
\text { it" }\end{array}$ & $\mathrm{x}$ \\
\hline \multirow{5}{*}{$\begin{array}{l}\text { Modular } \\
\text { triangle } \\
\text { event } \\
\text { planter }\end{array}$} & Questions & $\mathrm{x}$ \\
\hline & $\begin{array}{l}\text { Previous } \\
\text { works }\end{array}$ & $\mathrm{x}$ \\
\hline & Suggestions & $\mathrm{x}$ \\
\hline & Critiques & $\mathrm{x}$ \\
\hline & $\begin{array}{l}\text { "I've made } \\
\text { it" }\end{array}$ & $\mathrm{x}$ \\
\hline \multirow{5}{*}{$\begin{array}{l}\text { Modular } \\
\text { vegetable } \\
\text { protection } \\
\text { cage }\end{array}$} & Questions & $\mathrm{x}$ \\
\hline & $\begin{array}{l}\text { Previous } \\
\text { works }\end{array}$ & $\mathrm{x}$ \\
\hline & Suggestions & $\begin{array}{c}\text { "If you fill a tube with sand, it helps prevent kinking when bending. So, } \\
\text { you could use a heat gun (well ventilated!!!!) to soften the pvc and bend } \\
\text { the pipe. Or if you are using galvanized metal pipe (no heat gun } \\
\text { required)." }\end{array}$ \\
\hline & Critiques & $\mathrm{x}$ \\
\hline & $\begin{array}{l}\text { "I've made } \\
\text { it" }\end{array}$ & $\begin{array}{c}\text { "I made mine out of steel tubing and used chicken wire on them too. I } \\
\text { used mine as mulch cubes." }\end{array}$ \\
\hline \multirow{5}{*}{$\begin{array}{l}\text { Transporta } \\
\text { ble kitchen }\end{array}$} & Questions & $\mathrm{x}$ \\
\hline & $\begin{array}{l}\text { Previous } \\
\text { works }\end{array}$ & $\mathrm{x}$ \\
\hline & Suggestions & $\mathrm{x}$ \\
\hline & Critiques & $\mathrm{x}$ \\
\hline & $\begin{array}{l}\text { "I've made } \\
\text { it" }\end{array}$ & $\mathrm{x}$ \\
\hline \multirow{3}{*}{$\begin{array}{l}\text { Modular } \\
\text { greenhouse }\end{array}$} & Questions & $\mathrm{x}$ \\
\hline & $\begin{array}{l}\text { Previous } \\
\text { works }\end{array}$ & $\mathrm{x}$ \\
\hline & Suggestions & $\begin{array}{l}\text { "Is there any reason you could not skip the rectangles and just use } \\
\text { cable/zip ties to form a loop through each hole? Then they would act as }\end{array}$ \\
\hline
\end{tabular}


the hinge too. I hope my sketch will help explain.”

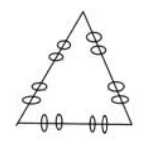

\section{Critiques \\ "I've made it"}

\section{$\mathrm{x}$}

"I will have to try this. I live in North Idaho were the growing season is very short so this seems like an excellent cost effective solution to jump start the growing season."

\begin{tabular}{|c|c|c|}
\hline \multirow{6}{*}{$\begin{array}{l}\text { Coffee cycle } \\
\text { reusing } \\
\text { coffee } \\
\text { ground }\end{array}$} & Questions & $\mathrm{x}$ \\
\hline & Previous & "Reminds me of my experience at \\
\hline & & http://www.instructables.com/id/Wire-Frame-Bike-Pannier" \\
\hline & Suggestions & $\begin{array}{l}\text { "I would suggest using metal file for the edges as not to cut yourself. } \\
\text { Also I would suggest using electricity tape / shrink wrap to cover cut } \\
\text { and exposed wires so not to cut yourself biking!" }\end{array}$ \\
\hline & Critiques & $\mathrm{x}$ \\
\hline & $\begin{array}{l}\text { "I've made } \\
\text { it" }\end{array}$ & $\begin{array}{c}\text { "I used tie raps to secure the basket to my bike. Its very secure and I } \\
\text { love it! " }\end{array}$ \\
\hline \multirow[t]{5}{*}{$\begin{array}{l}\text { Worm } \\
\text { composter }\end{array}$} & Questions & $\begin{array}{l}\text { "I am very interested in making this composter! I have a huge problem } \\
\text { with ants, although. They get in my composter and eat my worms. Have } \\
\text { you ever had this problem? If so, how do you address it? Thanks!" }\end{array}$ \\
\hline & $\begin{array}{l}\text { Previous } \\
\text { works }\end{array}$ & $\mathrm{x}$ \\
\hline & Suggestions & $\mathrm{x}$ \\
\hline & Critiques & $\mathrm{x}$ \\
\hline & $\begin{array}{l}\text { "I've made } \\
\text { it" }\end{array}$ & $\mathrm{x}$ \\
\hline \multirow{5}{*}{$\begin{array}{l}\text { Self } \\
\text { watering } \\
\text { bin }\end{array}$} & Questions & $\mathrm{x}$ \\
\hline & $\begin{array}{l}\text { Previous } \\
\text { works }\end{array}$ & $\mathrm{x}$ \\
\hline & Suggestions & $\mathrm{x}$ \\
\hline & Critiques & $\mathrm{x}$ \\
\hline & $\begin{array}{l}\text { "I've made } \\
\text { it" }\end{array}$ & $\mathrm{x}$ \\
\hline
\end{tabular}

